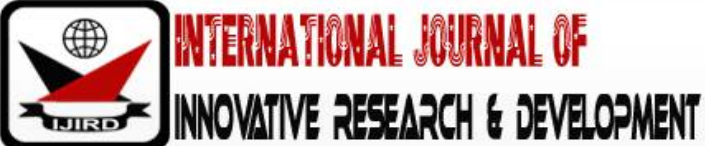

ISSN 2278-0211 (Online)

\section{Performance Evaluation of Alternative Dispute Resolutions (ADR) Among Stakeholders in Property Management in Ibadan Metropolis, Nigeria}

Adewole, Alexander Adebayo
Lecturer, Department of Estate Management,
The Federal Polytechnic, Ado Ekiti, Nigeria
Adewale, Peter Oluwatoyin
Principal Lecturer, Department of Architectural Technology,
The Federal Polytechnic, Ado Ekiti, Nigeria
Adebayo, Abimbola Adedayo
Principal Lecturer, Department of Architectural Technology,
The Federal Polytechnic, Ado Ekiti, Nigeria

\begin{abstract}
:
This paper examines the Performance evaluation of Alternative Dispute Resolution (ADR) among stakeholders in Property Management in Ibadan Metropolis. Primary data were collected with questionnaires administered on 100 Estate surveying and Valuation firms out of which 70 (70\%) were retrieved and analysed with the use of frequency counts and means rating of both 3 and 5 points Likert scale. Data from court and ADR centre were collected as a source of secondary data. The study showed that 100\% of respondents' firms engage in property management activities and also claimed awareness of existence of ADR centres in the case study area but have not subscribed to their mediation services. Analysis of performance of ADR centres is very high in terms of cost efficiency, timely settlement of disputes, maintenance of privacy and mutual acceptance of decision outcome by the parties as these are most significant having means rating above 2.5 compare to Litigation with rating far below 2.5 hence the study concluded that performance of ADR centres outweigh Litigation, even though the latter is far more sought after.

The study recommended sensitization among estate practitioners; the need to subscribe to services of ADR centres in the interest of stakeholders in Property Management, enshrine in the tenancy agreement the use of ADR mediation in settlement of disputes failure which court can entertain such; and also to empower ADR centres for enforcement of settlement between parties.
\end{abstract}

Keywords: Property management, alternative dispute resolution, litigation, Ibadan

\section{Introduction}

Property Management according to Baldwin (1994) is the total care of building during the operation stage. It is a main care for real estate (buildings), its components and occupiers for effective and efficient utilization of investment fund. Alternative Dispute Resolution (ADR) is dispute resolution out of courts. It involves any dispute settlements which are alternative to full scale court processes (Brown, Cervenak and Fairman, 2000; Lebovits and Hidalgo, 2010). Lebovits and Hidalgo (2010) specified that Alternative Dispute Resolution (ADR) is applicable to real estate cases in varieties of ways. Real estate cases range from residential and commercial landlord-and-tenant disputes, conflicts between cooperative boards and shareholders, and problems involving construction, leasing, subleasing, sales, broker client relationships, broker-agent relationships, appraisals, foreclosures, property-management issues, real estate partnerships and amongst others. According to Olukolajo (2012) Management of Landlord tenant relationship is an integral part of property Management; a property manager may be engaged at the inception of property life while some are engaged when the property or tenant(s) become problematic. Lebovits and Hidalgo (2010) posit that Landlord tenant relationships is contentious and are the frequent in Alternative Dispute Resolution engagements; mostly on tenants' failure to pay rent and Landlords' lack in obligations to effect repairs.

Performance is measured by ability of a system to meet set down indicators of assessment. It is aimed at determining effectiveness and efficiency of a programme (Burke and Hayward, 1999).Therefore, evaluation of performance of Alternative Dispute Resolutions (ADR) among stakeholders in Property Management is aimed at assessing its effectiveness and efficiency; in other words, its workability.

Evaluation is the act of considering or examining something in order to judge its value, quality, importance, extent or condition. It involves defining goals and specific measures of impact. It is a production entry point for analysis as it 
inevitably drains into problem definition, goals setting and other functional activities. Evaluation entails checking program of requirements, verify its correspondence with the desires and requirement for whom its intended (Voordt and Maarleveld 2006). Accordingly, Voordt and Wegan, 2005 posit that 'when evaluating consideration is given to what is to be evaluated, why, how, when, for whom and by whom"

There have been various write ups on Property Management but there seems to be paucity of publications on Performance Evaluation of Alternative Dispute Resolutions (ADR) among stakeholders in Property Management. It is against this background that the study is focused on Performance Evaluation of Alternative Dispute Resolutions (ADR) among stakeholders in Property Management in Ibadan Metropolis using appropriate indicators; topmost of these indicators are cost effectiveness, time efficiency, and acceptance of decision outcome of ADR by parties in comparison with Litigation and comparative analysis of impact of Litigation and ADR on parties. The aim of the paper is to appraise the workability of Alternative Dispute Resolution (ADR) mechanism in Property Management.

The paper is structured as follows: section 1 provides the introduction and the specific aim of the paper. Section 2 provides a brief review of literature on property management and alternative dispute resolution. The third section discussed study area, methodology and data analysis: Section 4 contains the result, discussion and concluding remarks for the study and recommendations.

\section{Literature Review}

Alternative Dispute Resolution (ADR) is dispute resolution out of courts. It involves any dispute settlement which are alternative to full scale court processes (Brown, Cevernak and Fairman, 2000; Lebovits and Hidalgo, 2010; Housing Rights, 2017; World Bank Group, 2011 and Moore, 2019). ADR is in various forms or categories namely; Negotiation, Mediation/Conciliation or Arbitration. The key subheadings are fully evidenced hereunder to include Negotiation, Mediation, Conciliation/Mediation, Arbitration, Property Management and benefits of Alternative Dispute Resolution.

\subsection{Negotiation}

Negotiation involves disputants attempt to reach a joint decision in a matter involved without involvement of the third party. It is a non-binding subject to parties' proceedings (Lebovits and Hidalgo, 2010; Brown, Cevernak and Fairman, 2000) and subject to parties' willingness to acceptant of agreement. Negotiation advantage over other ADR option is the cost effectiveness, third party are not involved hence no amount is spent or paid to the facilitator (third party). Also is the elimination of adversary bias as parties consensually agree.

\subsection{Mediation}

Mediation on the other hand involves intervention of the third party. The third party is referred to as a facilitator who merely encourages parties to dispute to come to settlement and does not take position himself (Brown, Cevernak and Fairman, 2000; Lebovits and Hidalgo, 2010 and Okpaleke et al, 2014). Mediation process is as contained in a written agreement; this specifies venue and format of mediation. The third party meets the disputants separately or together or adopts both. Written agreement is signed by parties once consensus is reached (Human Right,2017)

According to Callanan (2009) 'most property disputes are well suited to mediation, either as an alternative to court proceedings or at an earlier stage. Speed, cost effectiveness and maintenance of neighbouring relationships are all advantages in the area of property generally, including building contracts, rent reviews, tenancies, valuations, restrictions covenants, casements and right of way'.

\subsection{Conciliation/Mediation}

Conciliation and Mediation are used interchangeably (World Bank Group, 2011 and Law Reform 2010). World Bank Group (2011) stressed that the two varies but follow the same process with conciliation more evaluative than its facilitated cousin, mediation. Unlike, in mediation, the neutral in conciliation called councillor is free to make recommendations to parties for dispute settlement. Conciliation is most suited on dispute that requires expert opinion but in a confidential atmosphere.

\subsection{Arbitration}

In Arbitration, third party is empowered to decide how disputes are settled and it is binding on the disputants as if it is given by court as final judgment (Lebovits and Hidalgo, 2010; Housing Right, 2017). The party requires court order recognizing and enforcing its award. However, court will not enforce arbitral award that violate public policy (Law Reform, 2010), arbitral award is distinguished from court decision in that arbitration does not entailed appeal as done in court.

Arbitration is internationally recognised (Lebovits and Hidalgo, 2010; Jolly and Philpott,2009), as it provide the parties a level playing field to resolve dispute whether the parties are national of different countries, a government entity and an investor, two parties of unequal bargaining power, unrepresented adversaries; arbitration is impartial (Lebovits and Hidalgo, 2010). Arbitration is more formal and legally binding on parties (Housing Right, 2017). The independent arbitrator gives audience to both parties and makes his pronouncement which binds the parties to dispute.

\subsection{Property Management}

'Property management can be simplified as relating to the hard elements of the building; finding it, assessing its suitability against senior management brief, checking a long list of issues against needs and requirement and managing it including planning, access, communications, alteration' and the likes (Paxman 2007). 
Property management is not mere rent collection (Li 1997). According to Wong (1999) Property management is the work carried out to manage and maintain the development including its facilities at the level that will retain or enhance the value of the development, create a safe, functional and conducive living environment for occupants, keep or restore every facility in efficient working order and in good state of repair, and project a good appearance or image of the development.

Knight Frank (2013) categorized property management services as Rent and services charge collection, lease management and building maintenance, advice on tenants' request to assign, sublet or undertake alterations. It also includes coordination of specialist services, advice on security, energy and insurance procurement; accurate, incisive and timely client reporting.

This is also corroborated by Cornerstone Real Estate Services (2014) which stressed that property management services include the followings: Ensuring proper maintenance of all common area, building structure and mechanical systems, performance of scheduled property inspections, ensuring all vacant spaces are clean and show-ready for leasing/sale brokers. It also involves coordination of move-ins and move-outs, management of all building financial including tenant rent collection and vendor payment, obtaining competitive bid for property maintenance and liability insurance on developments and monitor an annual budget aimed at reducing cost and maximizing services. Others are initiating and overseeing real estate tax protests, preparation of year-end financial data and facilitate preparation of tax returns, preparation and submission of monthly management reports which detail each month's activities and review the financial health of the asset.

\subsection{Benefits and Deficiencies of $A D R$}

ADR has been of immense benefits; Lebovits and Hidalgo, 2010 and Housing Right, 2017 reported benefits such as timely resolution of dispute, cost efficiency, ability of parties to control proceeding; that is procedural rules and default mechanism, that is parties having control over choice of ADR venue, method, selection of neutral, neutral qualification (experience and background, compliance with obligation given as it was mutually agreed). Also, Brown, Cevernak and Fairman (2000) identified by passing ineffective and discredited court, increment in access to justice for disadvantaged groups, increase party's satisfaction with dispute resolution and support and completing court reform. Others are confidentiality of proceeding as proceeding are not done in public domain (McMurtry (nd); Lebovits and Hidalgo, 2010 and Housing Right, 2017), preserving and enhancing relationship between parties (McMurtry (nd); Brown, Cevernak and Fairman (2000). Despite these benefits, ADR is not without its deficiencies; Brown, Cevernak and Fairman, 2000 and Lebovits and Hidalgo, 2010 mentioned inability of ADR to: promote legal framework by setting of precedent like court, resolving cases that requires public sanction, resolving dispute between parties with wide difference in level of power and authority. Others are failure of parties in choosing neutral with a good grasp of law could result to waste of time, effort, money and causes heartache, inability of ADR to seek redress from injustice or human right problems and resolving disputes involving disputants or parties who refused or cannot participate.

\section{Study Area}

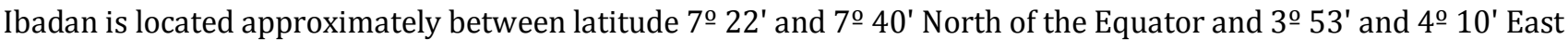
of the Greenwich Meridian (Figure 1). Ibadan is the capital of Oyo State; one of the 36 States of Nigeria (Figure.2). It comprises eleven local government areas. Administratively, Ibadan Metropolis consists of five local government areas; the inner city. These are Ibadan North, Ibadan North East, Ibadan North West, Ibadan South East and Ibadan South West with their respective headquarters at Agodi-Gate, Iwo Road, Onireke, Mapo and Oluyole. The remaining six local government areas constitute the less city. These are Akinyele, Egbeda, Ido, Lagelu, Oluyole and Ona-Ara.

As a typical Nigerian traditional city, it consists of three contrasting residential zones linked to three historical periods with their nature and characteristics determined by social, economic and physical patterns (Onibokun 1985). These are: the pre-colonial residential development which is the core or traditional zone; the colonial/pre-independence residential development referred to as the transition zone; and the post-independence residential development, also called the suburban (Onibokun 1985). Studies have shown that these residential zones are identifiable in Nigerian traditional cities.

The core area is the traditional area of the city comprising the indigenes and the first migrant settlement (Mabogunje 1968). The houses in the zone are closely built together, mainly of the traditional system, connected to one another with footpaths and lack accessibility by road. It also has minimal infrastructure and social amenities.

The transition zone was built and planned after the independence. According to Afon (2008), such district developed due to the pressure of the need to accommodate growing middle-income grade. It is regarded as the medium quality residential area. Facilities and services are available in this residential zone compared to the core.

The suburban zone is characterised by well-planned layouts. The ethnic composition and housing types are heterogeneous and there is provision of urban environmental services in the zone. The area houses the high-income group and the residents' educational status is higher than other zones (Adedimeji, Omololu and Dutolu, 2005). The zone is well serviced with facilities and has modern buildings.

Gbadegesin and Ojo; (2011) posited that Ibadan property market encounters pressure as a result of urbanization and population growth which increases demand for both residential and commercial properties. The supply of houses which has not been able to match demand, thereby creating housing deficit. The stakeholder's in property management forms a network chain of personnel such as manager, private investors, public and corporate organization, prospective tenants, existing tenants, lawyers, artisans and other services providers. Ibadan being the second largest city in Africa after 
Cairo in Egypt has the second largest stakeholders in property Management inNigeria after Lagos, it has a record of high cases of landlords' and tenants' disputes as given by courts (Assistant Director, Litigation, 2020)

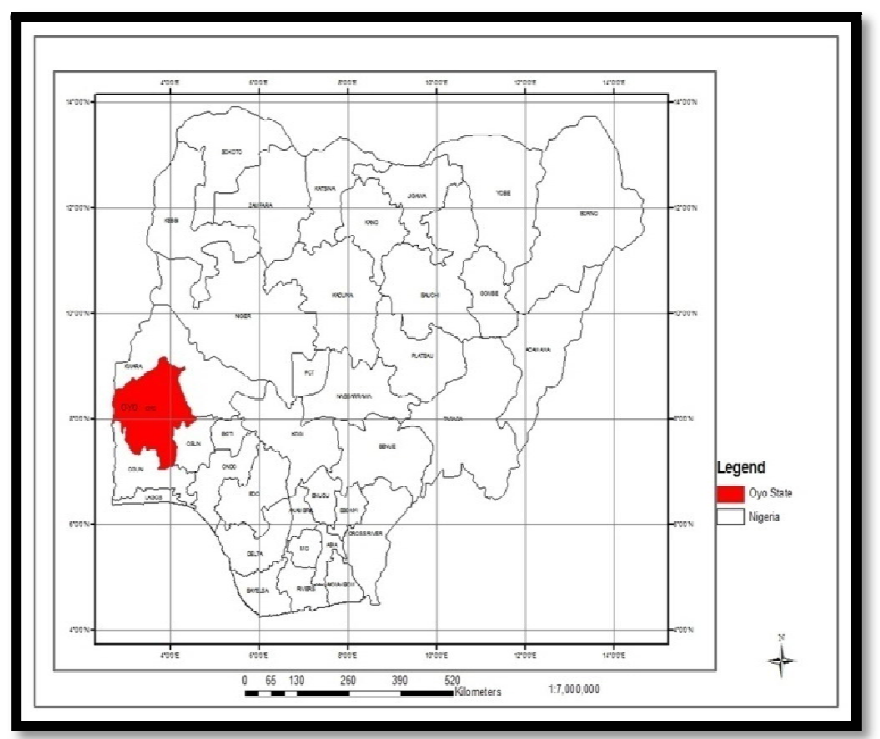

Figure 1: Map of Nigeria Showing Oyo State

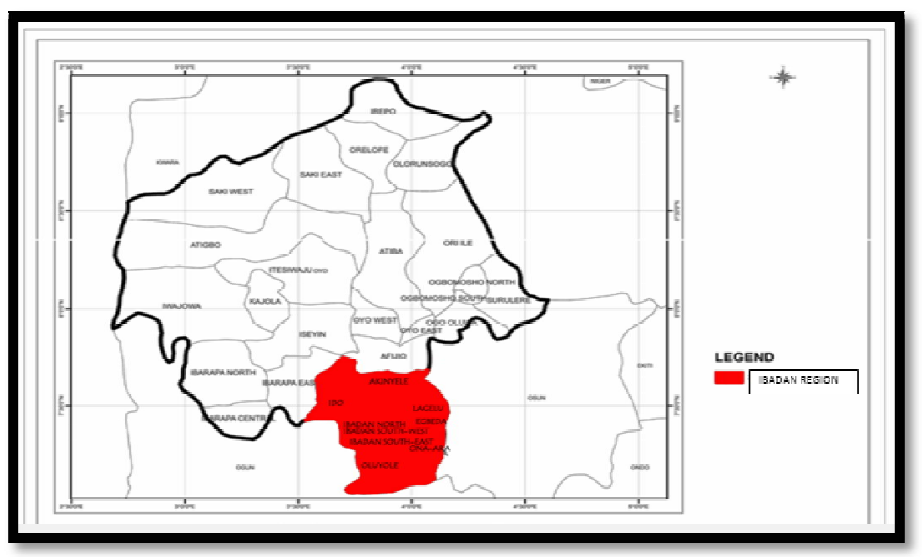

Figure 2: Map of Oyo State Showing the 11 Local Government Areas

Source: National Airspace Research and Development Agency (NASRDA) (2013)

\section{Methodology and Data}

The study is on Performance Evaluation of Alternative Dispute Resolutions (ADR) among stakeholders in Property Management in Ibadan Metropolis. The study adopted administration of questionnaire; and collection of data from court and ADR centre as a source of secondary data in addition to information from journals and periodicals.

The target population of the study was limited to estate surveying and valuation firms in the study area. A sample size of One Hundred (100) estate surveying and valuation firms was adopted. This figure was sourced from NIESV monthly meeting register from Oyo State NIESV Secretariat. The data collected were analyzed with the use of frequency counts and means rating of 3 and 5 points Likert scale. The survey achieved a total response of $70 \%$ (70 respondents).]

\section{Results and Discussions}

The questionnaires were analyzed and result are presented and discussed below;

\begin{tabular}{|c|c|c|}
\hline Years & Frequency & Percentage \\
\hline Yes & 70 & 100 \\
\hline No & 0 & 0 \\
\hline Total & 70 & 100 \\
\hline
\end{tabular}

Table 1: Engagement of firms in Property Management Source: Authors' field survey, 2020

Table 1 shows that all (100\%) estate firms in the study area are engaged in Property Management. This reveals that Property Management is included in the respondent's practice. 


\begin{tabular}{|c|c|c|}
\hline Property Management Activities & Frequency & Percentage \\
\hline Rent/lease renewal & 70 & 100 \\
\hline Demand for rent \& rent review & 70 & 100 \\
\hline Determination of lease/tenant ejection & 70 & 100 \\
\hline Management of Landlord Tenant relationship & 70 & 100 \\
\hline Routine inspection & 70 & 100 \\
\hline Supervision of repairs work & 70 & 100 \\
\hline Management of service charge & 70 & 100 \\
\hline Total & 70 & 100 \\
\hline
\end{tabular}

Table 2: Activities under Property Management Source: Authors' Field Survey, 2020

Table 2 shows that, all (100\%) of respondents' firms engage in property management activities listed. This reveals that all estate firms in the study area are fully engaged in property management activities.

\begin{tabular}{|c|c|c|c|c|c|c|c|c|c|c|}
\hline & Causes of Dispute & VF(5) & $F(4)$ & FF(3) & NF(2) & VIF(1) & CUM & TWV & MEAN & RANK \\
\hline 1 & Rent & 35 & 12 & 10 & 7 & 6 & 70 & 273 & 3.9 & $1^{\text {st }}$ \\
\hline 2 & Rent Review & 17 & 23 & 13 & 10 & 7 & 70 & 243 & 3.47 & $2^{\text {nd }}$ \\
\hline 3 & $\begin{array}{l}\text { Delay or nonpayment } \\
\text { of rates \& other } \\
\text { charges }\end{array}$ & 13 & 21 & 16 & 13 & 7 & 70 & 231 & 3.3 & $5^{\text {th }}$ \\
\hline 4 & Tenant failure to affect & 13 & 19 & 21 & 11 & 6 & 70 & 232 & 3.31 & $4^{\text {th }}$ \\
\hline 5 & $\begin{array}{l}\text { Landlord failure to } \\
\text { effect repair }\end{array}$ & 13 & 19 & 15 & 15 & 8 & 70 & 224 & 3.2 & $6^{\text {th }}$ \\
\hline 6 & $\begin{array}{c}\text { Tenant refusal to } \\
\text { vacate apartment }\end{array}$ & 16 & 21 & 16 & 10 & 7 & 70 & 239 & 3.4 & $3^{\text {rd }}$ \\
\hline 7 & $\begin{array}{l}\text { Noncompliance with } \\
\text { other tenancy } \\
\text { agreement (subletting, } \\
\text { conversion etc. }\end{array}$ & 14 & 19 & 19 & 10 & 8 & 70 & 231 & 3.3 & $5^{\text {th }}$ \\
\hline 8 & $\begin{array}{l}\text { Complaint about } \\
\text { tenants', nuisance- } \\
\text { Noise, Air pollution }\end{array}$ & 12 & 15 & 21 & 14 & 8 & 70 & 219 & 3.12 & $7^{\text {th }}$ \\
\hline 9 & $\begin{array}{c}\text { Complaint about } \\
\text { tenants' violent } \\
\text { behaviour }\end{array}$ & 10 & 16 & 14 & 21 & 9 & 70 & 207 & 2.95 & 8th \\
\hline 10 & $\begin{array}{l}\text { Complaint about } \\
\text { tenants' violent } \\
\text { behaviour }\end{array}$ & 9 & 13 & 21 & 19 & 8 & 70 & 206 & 2.94 & $9^{\text {th }}$ \\
\hline 11 & $\begin{array}{c}\text { Complaint about } \\
\text { tenant other } \\
\text { questionable character }\end{array}$ & 8 & 15 & 21 & 16 & 10 & 70 & 205 & 2.92 & $10^{\text {th }}$ \\
\hline
\end{tabular}

Table 3: Causes of Dispute in Property Management (VF- Very Frequent,

F- Frequent, FF- Fairly Frequent, NF- Not Frequent, VIF- Very Infrequent)

Source: Authors' Field Survey, 2020

Table 3 shows the causes of dispute in Property Management, using mean rating as yardstick of ranking these causes: Rent default, Rent Review, Delay or non-payment of Rates and other charges, Tenant failure to effect repair, Landlord failure to effect repairs, Refusal of tenant to vacate apartment at the expiration of lease where there is no option for renewal., Noncompliance with other tenancy Agreement such as obtaining landlord's consent before Subletting, conversion etc, Complaint about Tenant Nuisance ( Noise, Air pollution etc. ), Complaint about Tenant anti-social , Complaint about Tenant violent behaviour and Complaint about Tenants' other questionable characters has the mean rating of $3.9,3.47,3.3,3.31,3.2,3.4,3.3,3.12,2.95,2.94$ and 2.92 respectively. Rent default with mean rating of 3,9 is ranked first while complaint about Tenants' other questionable characters with mean rating of 2.92 is ranked least (10 th). This reveals that Rent default accounts for the major cause of dispute in property management; other listed variables above are also significant causes as they have mean rating above 2.5 


\begin{tabular}{|c|c|c|c|c|c|c|c|c|}
\hline & & SP(3) & P(2) & FP(1) & CUM & TWV & MEAN & RANK \\
\hline 1 & Litigation/Court & 15 & 46 & 9 & 70 & 146 & 2.01 & $2^{\text {nd }}$ \\
\hline 2 & ADR & 47 & 17 & 6 & 70 & 18 & 2.59 & $1^{\text {st }}$ \\
\hline 3 & Strong Arm Tactics & 2 & 1 & 9 & 12 & 17 & 0.242 & $3^{\text {rd }}$ \\
\hline
\end{tabular}

Table 4: Preference to Dispute Settlement

Source: Authors' field survey, 2020

Table 4 shows the approaches for settlement of dispute in Property Management, using mean rating as yardstick of ranking the estate surveyor and valuer's preference among these approaches: Litigation/Court, Alternative Dispute Resolution by Negotiation and Strong-Arm tactics/use of force has mean rating of 2.01, 2.59 and 0.241 respectively. Alternative Dispute resolution with mean rating of 2.59 is ranked first while strong arm tactics/ use of force is insignificantly ranked least. This reveals Alternative Dispute Resolution through Negotiation; the only significant approach (having mean rating above 2.5) is the most preferred among estate surveyors and valuers while Litigation is next option when ADR fails.

\begin{tabular}{|c|c|c|}
\hline & No & Frequency \\
\hline Yes & 57 & 81.4 \\
\hline No & 13 & 18.6 \\
\hline Total & 70 & $100 \%$ \\
\hline
\end{tabular}

Table 5: Awareness of Existence of ADR Centres in the Case Study Source: Authors' Field Survey, 2020

As shown in table 5, 81.4\% of estate surveyors and valuers are aware of the existence of ADR centres in the case study area while $18.6 \%$ claimed to be unaware; this reveals estate surveyors and valuers are aware of the existence of ADR centres in the case study area.

\begin{tabular}{|c|c|c|}
\hline & No & Frequency \\
\hline Yes & 22 & 31.4 \\
\hline No & 48 & 68.6 \\
\hline Total & 70 & $100 \%$ \\
\hline
\end{tabular}

Table 6: Estate Surveyors and Valuers Referral of Dispute to

ADR Centres for Settlement

Source: Authors' Field Survey, 2020

As shown in table 6, 31.4\% of estate surveyors and valuers have taken property management case to ADR centres in the recent times while $68.6 \%$ have not engaged ADR centres in settlement of dispute before. This is paradoxical; despite the huge number of estate surveyors and valuers that are aware of the existence of ADR centres only a handful of $31.4 \%$ engaged the services of the agency in dispute settlement. This confirms that the large number of estate surveyors and valuers that shows preference for ADR only engage Negotiation types of ADR and not Mediation or Arbitration.

\begin{tabular}{|c|c|c|}
\hline Reasons & Frequency & $\mathbf{\%}$ \\
\hline Settlement terms not binding on parties & 32 & 66.7 \\
\hline Party (ies) not compelled to participate & 10 & 20.8 \\
\hline Neutral selected could be bias & 6 & 12.5 \\
\hline Total & 48 & 100 \\
\hline
\end{tabular}

Table 7: Reasons for Non-Referral of Disputes to ADR Centres in the Case Study Source: Authors' Field Survey, 2020

As shown in table 7, 66.7\% of respondents claimed non-binding of settlement terms on parties account for reasons for non-referral of disputes to ADR centres, $20.8 \%$ and $12.5 \%$ cited non-compelling of parties to parties to participate in ADR and possibility of neutral selected to be bias as reasons. This reveals that property managers refusal to refer dispute to ADR as result of non-binding of settlement terms.

\begin{tabular}{|c|c|c|}
\hline Status of ADR Referred Cases & Frequency & Percentage (\%) \\
\hline Settled cases & 24 & $75 \%$ \\
\hline Unsettled cases (now in Court) & 3 & $9.4 \%$ \\
\hline Pending & 5 & $15.6 \%$ \\
\hline Total & 32 & $100 \%$ \\
\hline
\end{tabular}

Table 8: Status of Cases Referred to ADR Centres in the Case Study Source: Authors' Field Survey, 2020 
As shown in table $8,75 \%$ of disputes referred were successfully settled, $15.6 \%$ of cases are still pending while only 9.4\% were unsuccessful and later result to Litigation. This reveals almost all the cases referred to ADR centres are successfully settled.

\begin{tabular}{|c|c|c|c|c|c|c|c|c|}
\hline Performance Yardstick & SA(3) & $\mathbf{A ( 2 )}$ & FA(1) & D(0) & CUM & TWV & MEAN & RANKING \\
\hline Cost efficiency & 18 & 3 & 1 & 0 & 22 & 61 & 2.77 & $1^{\text {st }}$ \\
\hline Time efficiency & 17 & 3 & 2 & 0 & 22 & 59 & 2.68 & $2^{\text {nd }}$ \\
\hline Maintaining privacy & 12 & 9 & 1 & 0 & 22 & 55 & 2.50 & $4^{\text {th }}$ \\
\hline $\begin{array}{c}\text { Mutual acceptance of } \\
\text { decision }\end{array}$ & 15 & 5 & 2 & 0 & 22 & 57 & 2.60 & $3^{\text {rd }}$ \\
\hline Set precedence & 0 & 1 & 5 & 1 & 22 & 7 & 0.32 & $6^{\text {th }}$ \\
\hline Enforcement of ruling & 0 & 5 & 8 & & 22 & 18 & 0.82 & $5^{\text {th }}$ \\
\hline Simplify procedure & 10 & 16 & 6 & & 22 & 48 & 2.18 & $4^{\text {th }}$ \\
\hline
\end{tabular}

Tables 9: Comparative Analysis of Performance of ADR and Litigation ADR ADR (SA-Strongly Agreed, A-Agreed, FA-Fairly Agreed, D-Disagreed)

\section{Litigation}

\begin{tabular}{|c|c|c|c|c|c|c|c|c|}
\hline Performance Yardstick & SA(3) & $\mathbf{A ( 2 )}$ & FA(1) & D(0) & CUM & TWV & MEAN & RANKING \\
\hline Cost efficiency & 0 & 2 & 3 & 17 & 22 & 7 & 0.32 & $7^{\text {th }}$ \\
\hline Time efficiency & 0 & 4 & 2 & 16 & 22 & 10 & 0.45 & $6^{\text {th }}$ \\
\hline Maintaining privacy & 0 & 3 & 5 & 14 & 22 & 11 & 0.50 & $5^{\text {th }}$ \\
\hline Mutual acceptance of decision & 9 & 5 & 1 & 7 & 22 & 38 & 1.72 & $3^{\text {rd }}$ \\
\hline Set precedence & 17 & 13 & 1 & 1 & 22 & 58 & 2.6 & $1^{\text {st }}$ \\
\hline Enforcement of ruling & 16 & 3 & 1 & 2 & 22 & 55 & 2.5 & $2^{\text {nd }}$ \\
\hline Simplify procedure & 6 & 2 & 2 & 12 & 22 & 24 & 1.10 & $4^{\text {th }}$ \\
\hline
\end{tabular}

Table 10: Selected Landlord Tenant Cases from Court

Source: Authors' field survey, 2020

Table 9 shows the comparative analysis of Performance of ADR and Litigation settlement of dispute in Property Management, using mean rating as yardstick of ranking the performance: ADR has significantly performed (having mean ranking of 2.5 and above ) under cost efficiency (2.77), Time efficiency (2.68), maintaining privacy (2.5) and mutual acceptance of decision outcome (2.6) while Litigation has only significantly performed under Setting of Precedence (2.6) and Enforcement of Ruling (2.5).. This reveals that performance of ADR outweigh Litigation. The revelation in Table 8 was corroborated by secondary data collected from the court and ADR centre in the case study. Selected numbers of cases were collected from the two (ADR centre and Court) and compared, using time, cost and Judgement delivered/ settlement terms as yardstick for comparison. This is as presented in Table 10 and 11 below:

\begin{tabular}{|c|c|c|c|c|}
\hline $\mathbf{S} / \mathbf{N}$ & $\begin{array}{c}\text { Types of Real Estate } \\
\text { dispute }\end{array}$ & Duration of Case & $\begin{array}{l}\text { Likely Cost of } \\
\text { Litigation }\end{array}$ & Judgment delivered \\
\hline 1 & $\begin{array}{l}\text { Landlord-Tenant } \\
\text { dispute in recovery of } \\
\text { a } 3 \text { Bedroom Flat } \\
\text { apartment lying and } \\
\text { being at No 100, } \\
\text { Ifelodun Street, Ibadan }\end{array}$ & $\begin{array}{l}\text { 14th March, } 2016 \text { to } 22^{\text {nd }} \\
\text { February, } 2017(1 \text { year } \\
\text { approximately) }\end{array}$ & $\begin{array}{l}\text { Lawyers' fees paid by } \\
\text { disputants,Filling cost } \\
\text { paid by claimant and } \\
\text { other incidental } \\
\text { expenses. }\end{array}$ & $\begin{array}{l}\text {-Tenant given 3months to vacate } \\
\text { apartment } \\
\text {-Payment of arrears of Electricity } \\
\text { bill } \\
\text {-Payment of arrears of rent from } \\
\text { October. } 2015 \text { to January } 2016 \text { and } \\
\text { mesne profit till possession is } \\
\text { delivered } \\
\text {-Payment of Electricity \& Security } \\
\text { fee up till when possession is } \\
\text { delivered. }\end{array}$ \\
\hline 2 & $\begin{array}{l}\text { Landlord-Tenant } \\
\text { dispute on payment of } \\
\text { arrears of rent, and } \\
\text { settlement of } \\
\text { outstanding NEPA bills } \\
\text { on } 2 \text { B/R flat lying \& } \\
\text { being at Ifelodun } \\
\text { Cooperative Society } \\
\text { Building, Orita } \\
\text { Challenge, Ibadan }\end{array}$ & $\begin{array}{l}\text { 16 th March, 2016 }-17^{\text {th }} \\
\text { February, } 2017 \quad \text { (1year } \\
\text { approximately) }\end{array}$ & As above & 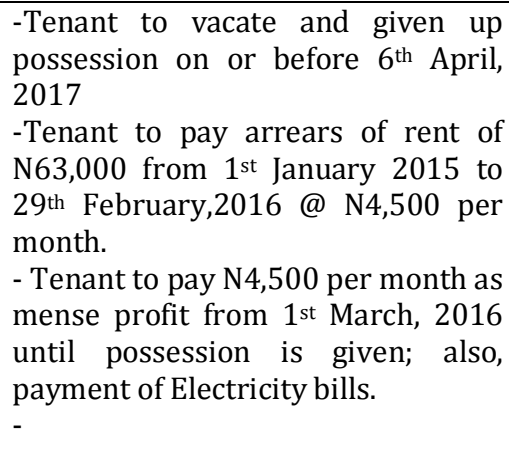 \\
\hline
\end{tabular}




\begin{tabular}{|c|c|c|c|c|}
\hline $\mathbf{S} / \mathbf{N}$ & $\begin{array}{l}\text { Types of Real Estate } \\
\text { dispute }\end{array}$ & Duration of Case & $\begin{array}{l}\text { Likely Cost of } \\
\text { Litigation }\end{array}$ & Judgment delivered \\
\hline 3 & $\begin{array}{l}\text { Landlord-Tenant } \\
\text { dispute in recovery of } \\
3 \mathrm{~B} / \mathrm{R} \text { flat situate and } \\
\text { being at Oladepo } \\
\text { House Idi Oro Area, } \\
\text { Sasa/Ojoo, Ibadan }\end{array}$ & $\begin{array}{lrr}23^{\text {rd }} \text { June,2017 } & \text { December, } \\
2017 \quad(6 & \text { months } \\
\text { approximately) } & \end{array}$ & As above & $\begin{array}{l}\text {-Tenant to pay balance of } \mathrm{N} 14,000 \\
\text { being arrears of rent from January } \\
\text { to Feb, } 2017 \text {. } \\
\text {-Mense profit of N7,000 from } 1^{\text {st }} \\
\text { March, } 2017 \text { till possession. } \\
\text {-Tenant to also bear cost of action }\end{array}$ \\
\hline 4 & $\begin{array}{l}\text { Landlord-Tenant } \\
\text { dispute on recovery of } \\
\text { an office space at } \\
\text { Cocoa House, Dugbe, } \\
\text { and Ibadan which } \\
\text { tenant occupied. }\end{array}$ & $\begin{array}{l}8^{\text {th }} \text { April, } 2015-16^{\text {th }} \text { June, } \\
2017 \text { (2years +) }\end{array}$ & As above & $\begin{array}{l}\text {-Defendant ordered to vacate on or } \\
\text { before } 23^{\text {rd }} \text { June, } 2017 \\
\text {-To pay N1,313,694.42 arrears of } \\
\text { rent from } 31^{\text {st }} \text { October, } 2014 \text { till } 18^{\text {th }} \\
\text { August, } 2015 \text { and mesne profit till } \\
\text { possession is given. } \\
\text {-Payment of arrears of Electricity } \\
\text { and other charges till possession } \\
\text { given }\end{array}$ \\
\hline 5 & $\begin{array}{l}\text { Landlord-Tenant } \\
\text { dispute on recovery of } \\
\text { possession and } \\
\text { payment of arrears of } \\
\text { rent of } 2 \text { B/R flat at No } \\
3 \text {, Balogun Amosun } \\
\text { Street, Alake, Ibadan } \\
\text { Possession of a } 3 \text { B/R } \\
\text { flat at No 18, } \\
\text { Fafunmilayo Street off } \\
\text { Ojoo Express, Iwo } \\
\text { Road. }\end{array}$ & $\begin{array}{l}14^{\text {th }} \text { November,2016 to } 8^{\text {th }} \\
\text { February,2017(3months) } \\
1^{\text {st }} \text { September, } 2016-7^{\text {th }} \\
\text { February,2017 ( } 6 \text { months) }\end{array}$ & As above & $\begin{array}{l}\text {-Tenant to vacate and delivered up } \\
\text { vacant possession on or before } 31^{\text {st }} \\
\text { March, } 2017 \text {. } \\
\text {-Tenant to pay arrears of rent in the } \\
\text { sum of } 125,000 \text { from August } 2015 \\
- \text { October } 2016 \text { at rate of } \\
\text { N8,335/month } \\
\text {-Tenant to Road. pay arrears of rent } \\
\text { N167,000 for February } 2015 \text { to } \\
\text { August } 2016 \text {. } \\
\text {-To pay mense profit at the rate of } \\
\text { N12,500/month for September } \\
2016 \text { until possession. }\end{array}$ \\
\hline 6 & & & & $\begin{array}{l}\text {-To pay N13,000 (security fee for } 2 \\
\text { years and } 7 \text { months) } \\
\text {-To pay cost of Litigation N6,000. }\end{array}$ \\
\hline 7 & $\begin{array}{l}\text { Landlord-Tenant } \\
\text { dispute on possession } \\
\text { of a room situate at } \\
\text { NW7/429 Ayetoro } \\
\text { Street, Eleyele, Ibadan }\end{array}$ & $\begin{array}{l}\text { 17th January,2017 }-16^{\text {th }} \\
\text { June, } 2017(6 \text { months })\end{array}$ & As Above & $\begin{array}{l}\text {-Tenant to deliver possession on or } \\
\text { before } 30^{\text {th }} \text { July, } 2017 \text {. } \\
\text {-Tenant to pay N20,000 as mense } \\
\text { profit from December } 2016 \text { to July } \\
2017 \text {. }\end{array}$ \\
\hline 8 & $\begin{array}{l}\text { Recovery of a } 2 \text { B/R } \\
\text { flat situate at } \\
\text { SW6/508B Agbokojo, } \\
\text { Ibadan }\end{array}$ & $\begin{array}{l}17 / 3 / 17-16 / 6 / 17 \quad(3 \\
\text { months })\end{array}$ & As Above & $\begin{array}{l}\text {-Tenant to pay arrears of rent of } \\
\text { N180,000 and mense profit from Jan } \\
2016 \text { till May } 2017\end{array}$ \\
\hline 10 & $\begin{array}{l}\text { Possession of a room } \\
\text { at Alakija Zone 2, } \\
\text { Boluwaji Area, Iwo } \\
\text { Road, Ibadan } \\
\text { Possession of a Room } \\
\text { apartment } \\
\text { SW8/535 NTC Road, } \\
\text { Oke Ado, I }\end{array}$ & $\begin{array}{l}9^{\text {th }} \text { February, } 2017 \text { to } 5^{\text {th }} \\
\text { May, } 2017 \text { ( } 3 \text { months) } \\
\text { 9th January, } 2017 \text { to } / 6^{\text {th }} \\
\text { June } 2017 \text { (6months) }\end{array}$ & - As Above & $\begin{array}{l}\text {-Tenant to deliver vacant possession } \\
\text { on or before } 6^{\text {th }} \text { June, } 2017 \text {. } \\
\text {-To pay N6,000 mense profit from } \\
\text { January } 2017 \text { to May 2017; and } \\
\text { N1,200/month till vacant } \\
\text { possession. } \\
\text {-Tenant to deliver vacant possession } \\
\text { on or before } 30^{\text {th }} \text { August, } 2017 \text {. } \\
\text {-Tenant to pay N20,000 as mesne } \\
\text { profit from January } 2017 \text { till August } \\
2017 \text {. }\end{array}$ \\
\hline 11 & $\begin{array}{l}\text { Possession of } 3- \\
\text { bedroom apartment at } \\
\text { No 33, Ososami, } \\
\text { Ibadan }\end{array}$ & $\begin{array}{l}14^{\text {th }} \text { December,2016 to } 16^{\text {th }} \\
\text { June, } 2017(6 \text { months })\end{array}$ & As above & $\begin{array}{l}\text {-Tenant to delivered vacant } \\
\text { possession on or before } 30 \text { th } \\
\text { July,2017 } \\
\text {-Tenant to pay N280,000 arrears of } \\
\text { rent from September } 2015 \text { to July } \\
2017 \text { and mense profit of N12,500 } \\
\text { monthly from } 1^{\text {st September,2015 }} \\
\text { until possession is delivered. }\end{array}$ \\
\hline
\end{tabular}

Table 11

Source: Authors' field survey, 2020

As shown on table 10, cases are dispensing landlord tenant cases in court takes an average of 6months to 2years (average of 1year). Cost of litigation includes payment made to Attorneys, filling of cases and other incidental expenses. Defendants usually tenants are order to vacate apartment at a particular date failure which ejection would be carried out. 


\begin{tabular}{|c|c|c|c|c|}
\hline & Types of Real Estate dispute & Duration & $\begin{array}{c}\text { Cost } \\
\text { incurred }\end{array}$ & Settlement term \\
\hline 1. & $\begin{array}{l}\text { Landlord - Tenant (of a property at No 3, } \\
\text { Oloke Street, Oluyole Extension) dispute on } \\
\text { defamation of tenant's character. Landlord } \\
\text { requested tenant to quit property over } \\
\text { autism child }\end{array}$ & $\begin{array}{c}0^{\text {th }} \text { July,2018 }-16^{\text {th }} \\
\text { October } 2018\left(\mathbf{2}^{1 / 2}\right. \\
\text { months })\end{array}$ & $\begin{array}{c}\text { N5,000 only } \\
\text { paid by each } \\
\text { party }\end{array}$ & $\begin{array}{l}\text { - } \quad \text { Tenant requested for 3-month } \\
\text { unexpired term which landlord } \\
\text { paid. } \\
\text { - } \quad \text { Matter settled amicably and } \\
\text { tenant vacated on agreed date. }\end{array}$ \\
\hline 2. & $\begin{array}{l}\text { Landlord and Tenant dispute on payment of } \\
\text { arrears of rent on property at Plot 24, } \\
\text { Ogunsola layout, Fasogbon Abegunde Orita } \\
\text { Challenge, Ibadan }\end{array}$ & $\begin{array}{l}\text { 19th June, } 2018 \text { - } \\
\text { 12th July, } 2018 \text { (3 } \\
\text { weeks) }\end{array}$ & As above & 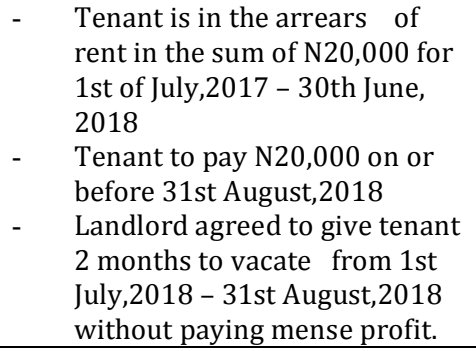 \\
\hline 3 & $\begin{array}{l}\text { Landlord and tenant dispute on recovery of } \\
\text { flat at No 6/9003, Ijokodo WAEC, Ibadan. } \\
\text { The tenant has refused to leave at the } \\
\text { expiration of quit notice \& } 7 \text { days owner } \\
\text { intension to take possession. }\end{array}$ & $\begin{array}{c}\text { 26 }^{\text {th }} \text { June, } 20018 \text { - } \\
18^{\text {th }} \text { July,2018 (3 } \\
\text { weeks) }\end{array}$ & As above & 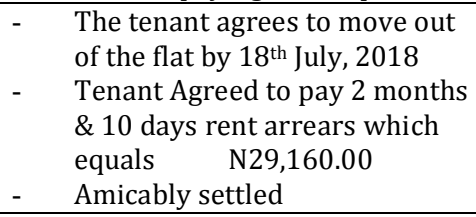 \\
\hline 4 & $\begin{array}{l}\text { LL -TT dispute involving recovery of } \\
\text { arrears of rent from } 25 / 8 / 17-24 / 8 / 18 \& \\
\text { utility bill in the sum of N138,600 a } \\
\text { property at } 3 \text { bedrooms flat at No } 3 \text {, Alhaji } \\
\text { Laka Ladipo, Felele }\end{array}$ & $\begin{array}{l}\text { 27th April,2018 - } \\
\text { 27th April.2018 (1 } \\
\text { day) }\end{array}$ & As above & $\begin{array}{l}\text { - } \\
\text { benant agrees to pay on or } \\
\text { covers monthly rent from } 25^{\text {th }} \\
\text { August, } 2017-24^{\text {th }} \\
\text { August, } 2018\end{array}$ \\
\hline 5 & $\begin{array}{l}\text { Lessor - Lesee (Vulcanizer Association) } \\
\text { dispute on from recovery of land used by } \\
\text { the lessee at Oluseyi Roundabout, Ring } \\
\text { Road, Ibadan. } \\
\text { Notice was served on respondent on lessor } \\
\text { intention to sell land at expiration of } \\
\text { lessee tenancy on } 31^{\text {st }} \text { July,2018 in which } \\
\text { lessee failed to give up possession }\end{array}$ & $\begin{array}{c}\text { 16 } 6^{\text {th }} \text { August, } 2018- \\
11^{\text {th }} \text { October,2018 } \\
\text { (7 weeks) }\end{array}$ & As above & 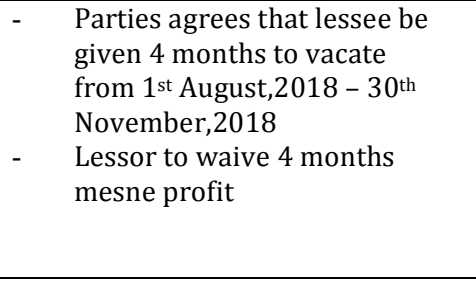 \\
\hline 6 & $\begin{array}{l}\text { Landlord and Tenant dispute on payment of } \\
\text { arrears of rent from Jan, } 2018 \text { till 10th } \\
\text { October,2018 on } 2 \text { Shops at Odedele } \\
\text { Odeleru Street, Challenge, Ibadan. Tenant } \\
\text { prayed for continuation of tenancy and } \\
\text { asked for more time to pay. }\end{array}$ & $\begin{array}{c}10^{\text {th }} \text { October,2018 - } \\
12^{\text {th }} \text { October,2018 } \\
\text { (2 days) }\end{array}$ & As above & 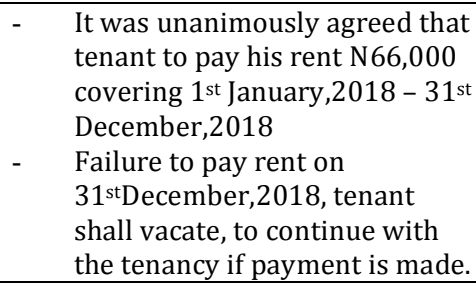 \\
\hline 7 & $\begin{array}{l}\text { Landlord and tenant dispute on recovery of } \\
1 \text { Room rented to respondent, tenant } \\
\text { refused to vacate despite issuance of quit } \\
\text { notice and upon expiration, Tenant owing } \\
\text { rent in arrears, electricity bill \& Security } \\
\text { bill. }\end{array}$ & $\begin{array}{c}25^{\text {th }} \text { April,2018 }-4^{\text {th }} \\
\text { June,2018 } \\
\text { weeks) }\end{array}$ & - As above & 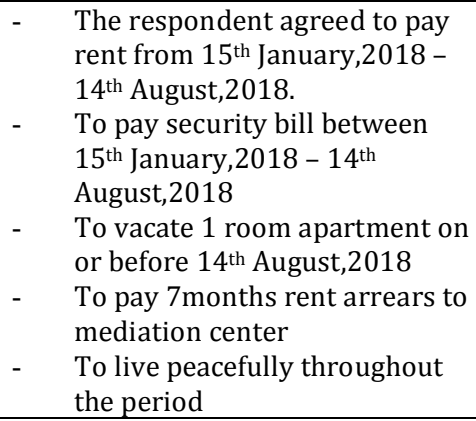 \\
\hline 8 & $\begin{array}{l}\text { Landlord and tenant - dispute in a } 3 \\
\text { Bedroom Flat at Yemetu Alawada Area, } \\
\text { Yemetu, Ibadan. } \\
\text { Tenant reported that Landlord sent Police } \\
\text { (SARS) to arrest and tortured him } \\
\text { Landlord Claims } \\
\text { That tenant makes trouble with other } \\
\text { tenants, and is in arrears of rent since } \\
\text { February, } 2018 \text { and also failed to pay utility } \\
\text { bills. }\end{array}$ & $\begin{array}{c}18^{\text {th }} \text { April, } 2018- \\
28^{\text {th }} \text { Aprl,2019 } \\
\text { (10 days) }\end{array}$ & As above & $\begin{array}{ll}\text { - } & \text { Applicant shall vacate } \\
\text { respondent property and } \\
\text { deliver possession of property } \\
\text { on or before } 31^{\text {st }} \text { May, } 2018 . \\
\text { - To pay arrears of rent in the } \\
\text { sum of N18,000 to respondent } \\
\text { on or before } 30^{\text {th }} \text { July,2018 } \\
\text { which covers from } 1^{\text {st }} \\
\text { February,2018 - } 31^{\text {st }} \text { April, } \\
\text { 2018 at N6,000 per month. } \\
\text {-The applicant to pay utility bill } \\
\text { before vacating } \\
\text { - To allow agent of respondent } \\
\text { to do pre-vacation inspection } \\
\text { on } 30^{\text {th }} \text { May, } 2018 . \\
\text { To make peace till he vacates. }\end{array}$ \\
\hline
\end{tabular}


As shown on table 12 above, settlement of dispute referred to ADR centres takes an average of few weeks, and cost only involves paltry N5,000 each made by both parties. Tenants are made to agree when to leave if need be.

\section{Conclusion and Recommendations}

This paper has revealed that all estate surveying and valuation firms in the study area are engaged in property management practice; and all activities involves in property management. There are many causes of disputes in property management; topmost of them is the tenant failure or inability to perform their rental obligations as at when due. Most estate firms engage in Negotiation with tenants for settlement of disputes prior to Litigation as handful numbers engage ADR centres for Mediation even when majority are aware of the existence of ADR centres in the case study area. Very high frequency of cases referred to ADR centres by the handful numbers of property managers were successfully settled and only few of such find their way back to court for Litigation.

Analysis of performance of ADR centres is high in terms of cost efficiency, timely settlement of disputes, maintenance of privacy and mutual acceptance of decision outcome of settlement compare to Litigation. Paradoxically, Litigation is mostly sought after in solving management dispute. This may not be unconnected with property managers sticking to old ways of doing things, refusal to embrace new concepts or ignorant of benefits and competitive performances of ADR centers.

A cursory look at the selected cases from court on ADR centres presented in Table 10 and 11 corroborates the performance of ADR over Litigation. In Litigation (court); Landlord- tenant cases are dispersed at the average of 1 year, at a higher cost as payments are made to Attorneys, to court for filling of cases and other incidental expenses. Tenants that are forcefully ejected suffered psychological defect or post-traumatic stress disorder while landlord property investments suffer during Litigation. Conversely, ADR cases are timely dispensed at little or no cost (see table 10). Tenants are not forcefully ejected are made to agree to leave quietly and are not likely to suffer trauma. Landlord investments may not likely suffer because cases are timely settled.

This paper reveals the inherent benefits and performances of ADR centers and sensitizes estate management practitioners of the need to embrace ADR in the interest of stakeholders in property management for optimum performance in cost and time measure.

This paper further reveals the need for Government at all levels to strengthen or empower ADR centres' Mediation to be binding on parties like Arbitration so as to make it worthwhile and thereby acceptable to stakeholders. With this landlord- tenants' cases which constitute high percentage of civil cases (Deputy Registrar, Litigation, High Court of Justice, Oyo state,2020)if are handled by ADR centers, will defray court most of civil cases and court can now concentrate on criminal cases. Settlement of property management dispute by ADR centers should be a clause in tenancy agreement to be signed by parties prior to tenant taking over property.

Alternative Dispute Resolution as a means of dispute settlement in Property Management should also be included in curriculum of estate management discipline in tertiary institutions offering Estate Management in Nigeria and abroad.

\section{References}

i. Adedimeji, A., Omololu, O., and Dutolu, O. (2005): Urban Slum Residence, HIV- risk Perception and Constraints to Protective Behaviour among Young People in Ibadan, Nigeria.

ii. Afon, O.A (2005): Solid Waste Management in selected cities of Oyo State. A unpublished Ph.D thesis submitted to the department of Urban and Regional Planning, Obafemi Awolowo University, Ile Ife

iii. Baldwin (1994), Property Management in Hong Kong: An overview. Property Management (4), pg 18-23, MCB University Press, 0263-7472

iv. Brown, S; Cervenak, C and Fairma, D (2000): Alternative Dispute Resolution Practitioner Guide.

v. Burke, T. and Hayward, D. (1999): Performance indicators and Social Housing in Australia. Institute for social Research Swinbume University of Technology, Melboume, Australia

vi. Callanan, T. (2009): Neutralising Property Disputes: The Role of Mediation. 14(4) CPLJ 98.

vii. Cornerstone Commercial Properties (2014) Commercial Real Estate Services. Property Management pg 1-3

viii. Frank, K. (2013), European Property Management: Property Management Service pg 6.

ix. Gbadegesin, J. T and Ojo, 0 (2011): An appraisal of Property Management Practice in Metropolitan Ibadan, Nigeria. The Built and Human Environment Review, Volume 4Special Issue 1

x. Housing Right (2017): Alternative Dispute Resolution in the Private Rented Sector:: examining the case for the establishment of an independent dispute resolution service for tenants and landlords in Northern Ireland

xi. Jolly, A and Philpott, J (2009): The handbook of Intellectual Property Management. Second Edition. Kogan lage, London.

xii. Law Reform (2010): Alternative Dispute Resolution: Mediation and Conciliation. Law Reform Commission. ISSN 1393-3132

xiii. Lebovits, G and Hidalgo, L.R (2010): Alternative Dispute Resolution in Real Estate Matters. The New York Experience

xiv. Li, L.H (1997): Property Management in China. Opportunities and Problems. Property Management. Vol, 15, No 1. P C-11 MCB University Press ISSN 02637472

xv. McMurtry, B (nd): Advantages and Disadvantages of Dispute Resolution Process. AORLANDO@BLANEY.COM

xvi. Moore, C.W (2019): A feasibility Assessment on the Introduction of Alternative Dispute Resolution (ADR)/Collaborative dispute Resolution (CDR) to Resolve Land Dispute in Myanmar. Norwegian Refugee Council 
xvii. Mabogunje, A (1968): Urbanization in Nigeria. London: University of London Press,

xviii. Okpaleke, F.C; Otegbulu, A.C and Emele, C.R (2014): Mitigating Risk Impact of Disputes on Real Estate Business and Investment in Lagos: The Alternative Dispute Resolution (ADR) Approach. Covenant Journal of Business and Social Sciences (CJBSS) Vol.6, No. 1

xix. Olukolajo, M A (2012) Managing conflicts relating to property management: The role of estate

xx. $\quad$ surveyors In: Laryea, S., Agyepong, S.A., Leiringer, R. and Hughes, W. (Eds) Procs 4th West Africa Built Environment Research (WABER) Conference, 24-26 July 2012, Abuja, Nigeria, 1141-1153.

xxi. Onibokun, A.G (1985). Housing in Nigeria: A Book of Reading, Nigeria. Nigeria Institute of Social and Economic Research (NISER).

xxii. Paxman, D. (2007), Facilities Management in Practice. International Facilities and Property Information Limited. $1^{\text {st }}$ Educating. ISBN: 978-0-914237-40-5.

xxiii. Wong, K.S (1999). Property Management in Private Practice, Unpublished Lecture Notes, Kurus Pengunesan Hartanahdan Facilities 20-23, Sept INSPEN

xxiv. Voordt, T.J.M Van-derand Wegan, H.B.R (2005). Architecture in Use. An Introduction to the Programming, Design and Evaluation of Building. Oxford Architectural Press (2005)

xxv. Voordt, T.J.M Van-derand Maarleveled, M. (2006). Performance of office Building from a User's Perspective. www.researchgate.net/publication/277228368.

xxvi. World Bank Group (2011): Alternative Dispute Resolution Guidelines. 1818 H Street, N.W. Washington D.C,20433 